\title{
HUBUNGAN ANTARA ASUPAN ENERGI DAN AKTIFITAS FISIK DENGAN KEBUGARAN JASMANI
}

\author{
Muhammad Ridwan ${ }^{1}$, Naintina Lisnawati ${ }^{2}$, Emillia Enginelina ${ }^{3}$ \\ ${ }^{1,2}$ Sekolah Tinggi Ilmu Kesehatan Holistik, Purwakarta \\ ${ }^{3}$ Rumah Sakit Umum Daerah Bayu Asih, Purwakarta
}

\begin{abstract}
ABSTRAK
Latar Belakang: Kebugaran atau yang sering dikaitkan dengan daya tahan kardiorespiratori adalah hal yang berhubungan dengan kemampuan seseorang dalam melakukan kegiatan dan atau aktifitas dengan efektif dan tanpa disertai kelelahan yang berlebihan. Dari hasil survei oleh tim pengembang Sport Development Index (SDI) tahun 2005 menunjukkan tingkat kebugaran jasmani anak sekolah dasar (SD) di seluruh Indonesia cenderung rendah.

Tujuan:Untuk mengetahui hubungan antara asupan energi dan aktifitas fisik dengan kebugaran jasmani pada siswa kelas V SD-IT Albina Purwakarta tahun ajaran 2016.

Metode:Desain penelitian yang digunakan dalam penelitian ini adalah crosssectional dengan pengambilan sampel menggunakan metode stratified random sampling dan systematic random sampling. Sampel penelitian ini sebesar 33 siswa dari kelas V SD-IT Albina Purwakarta.Data aktifitas fisik diukur menggunakan recall aktifitas fisik 24 jam, asupan energi menggunakan recall 24 jam, dan kebugaran jasmani menggunakan metode Harvard Step Test. Analisis data menggunakan uji Pearson Product Moment dan Rank-Spearman.

Hasil: Asupan energi dari sebagian besar responden (54,5\%) masuk dalam kategori defisit, aktifitas fisik seluruh responden (100\%) tergolong ringan dan kebugaran jasmani responden sebesar $(81,8 \%)$ termasuk dalam kategori kurang. Tidak ada hubungan antara asupan energi dan aktifitas fisik dengan kebugaran jasmani $(\mathrm{p}=0,413 ; \mathrm{p}=0,297)$
\end{abstract}

Simpulan: Tidak ada hubungan antara asupan energi dan aktifitas fisik dengan kebugaran jasmani.

Kata kunci: Asupan energi, aktifitas fisik, kebugaran, Harvard Step Test

\author{
Korespondensi : \\ Naintina Lisnawati \\ Sekolah Tinggi Ilmu Kesehatan Holistik Purwakarta \\ J1. Veteran No. 272 Ciseureuh Purwakarta, Jawa Barat 41118 \\ Email : naintinalisnawati@gmail.com \\ Phone : 0856-4180-0529
}




\title{
THE RELATIONSHIP BETWEEN ENERGY INTAKE AND PHYSICAL ACTIVITIES WITH PHYSICAL FITNESS
}

\begin{abstract}
Background: Physical fitness or cardiorespiratory fitness is associated with a person's ability to perform activities or activities effectively and without excessive fatigue. Results of the survey by a team of developers Sport Development Index (SDI) in 2005 shows the level of physical fitness elementary school across Indonesia are comparatively low.

Objective:To determine the relationship between energy intake and physical activity with the physical fitness of students from SD-IT Albina Purwakarta in school year 2016
\end{abstract}

Methods: This study used cross-sectional design with stratified random sampling and systematic random sampling methods in the sampling process.A numberof 33 students from class V SD-IT Albina Purwakarta participated in this study. Data of physical activity was measured using 24-hour recall physical activity, energy intake using 24-hour recall, and physical fitness using the Harvard Step Test.Data analysis using Pearson Product Moment and Rank-Spearman test.

Result:Energy intake of the majority of respondents (54.5\%) fall into the category deficits, physical activity all respondents (100\%) is relatively light and the physical fitness of the respondents $(81.8 \%)$ included in the low category. There was no significant association between energy intake and physical activity with physical fitness ( $\mathrm{p}=0,413 ; \mathrm{p}=0,297$ ).

Conclusion: There was no significant association between energy intake and physical activity with physical fitness.

Keywords: Energy intake, Physical activity, physical fitness, Harvard Step Test 


\section{PENDAHULUAN}

Kebugaran jasmani adalah kemampuan tubuh seseorang untuk melakukan tugas atau pekerjaan sehari-hari tanpa menimbulkan kelelahan yang berarti. Seseorang dengan kebugaran jasmani yang baik diharapkan akan mampu bekerja dengan produktif dan efisien, tidak mudah terserang penyakit, belajar menjadi lebih semangat, serta dapat berprestasi secara optimal. ${ }^{1}$

Berdasarkan hasil survey yang dilakukan oleh tim pengembang Sport Development Index (SDI) tahun 2005yang meneliti kebugaran jasmani pelajar SD, SMP dan SMA di seluruh Indonesia menunjukkan tingkat kebugaran yang cenderung rendah. Hasilnya tidak ada kebugaran jasmani anak yang baik sekali (nol persen), baik hanya 5,66 persen, sedang 37,66 persen, kurang 45,97 persen, dan kurang sekali 10,71 persen. Demikian pula pada tahun 2006, SDI menyurvey kebugaran jasmani masyarakat Indonesia berusia 25-30 tahun. Hasilnya kategori baik sekali hanya 5,05 persen, baik 5,15 persen, sedang
13,55 persen, kurang 43,90 persen dan kurang sekali 37,40 persen. ${ }^{2}$

Kebugaran jasmani dipengaruhi banyak faktor, salah satunya adalah aktifitas fisik. Aktivitas fisik adalah setiap gerakan tubuh yang dihasilkan oleh otot rangka yang memerlukan pengeluaran energi. ${ }^{3}$ Sebagaimana yang dikemukakan bahwa di antara tujuan pendidikan jasmani yang penting adalah tercapainya derajat kebugaran jasmani yang berpengaruh pada kemampuan siswa dalam melakukan kegiatan fisik dengan baik. $^{4}$

Tingkat Kebugaran Jasmani berpengaruh terhadap tinggi rendahnya prestasi belajar siswa. Siswa yang mempunyai tingkat kebugaran jasmani yang baik akan memiliki daya tahan, daya konsentrasi, dan ketersediaan tenaga untuk melakukan aktivitas belajar. ${ }^{5}$

Asupan gizi merupakan salah satu faktor lain yang menentukan kebugaran jasmani. Asupan gizi digunakan untuk sumber energi dalam melakukan aktifitas atau pekerjaan. ${ }^{6}$ Asupan energi yang cukup dari makanan berpengaruh 
pada produktifitas dan kebugaran seseorang khususnya pada anak sekolah. ${ }^{7}$ Sekolah Dasar Islam Terpadu (SD-IT) Al-Bina Purwakarta adalah sebuah sekolah yang terletak di kota Purwakarta dengan pola hidup perkotaan, selain itu merupakan sekolah yang menerapkan kegiatan belajarmengajar secara terpadu sehingga membutuhkan kebugaran jasmani yang baik. Melihat latar belakang di atas maka peneliti ingin melakukan penelitian untuk mengetahui hubungan Asupan Energi dan Aktifitas Fisik terhadap Kebugaran Jasmani di SD-IT Al-Bina Purwakarta.

\section{METODE}

Penelitian ini merupakan jenis penelitian observasional dengan desain cross sectional, dimana pengambilan data dilakukan pada satu waktu (Point Time Approach).Sampel dalam penelitian ini diambil dari populasi siswa Kelas V SD-IT Albina Purwakarta yang berjumlah 89 orang dengan terbagi ke dalam tiga ruang kelas.Dari hasil perhitungan dengan rumus koefisien korelasi diperoleh jumlah sampel minimal adalah 30 subjek, namun untuk antisipasi drop out maka ditambahkan 10\%, sehingga jumlah sampel menjadi 33 orang.Cara pengambilan sampel dilakukan dengan Stratified Random Sampling dan systematic random sampling hingga jumlah sampel mencapai jumlah yang diinginkan yaitu sebanyak 33 orang.

Instrument yang digunakan dalam penelitian ini meliputi kuisioner, formulir food recall 24 jam, formulir recall aktifitas fisik, lembar observasi, stopwatch, timbangan, microtoise, metronome, bangku tes, daan software statistik. Pengukuran asupan energi mengacu kepada Angka kecukupan Gizi (AKG) untuk anak usia 10-12 tahun, aktifitas fisik diukur dengan menggunakan wawancara dengan menggunakan Formulir Recall Aktifitas Fisik yang diklasifikasikan dengan perhitungan Resting Energy Expenditure (REE), sedangkan penilaian kebugaran menggunakan metode Harvard Step Test.

Analisisdata dilakukan dua tahapan yaitu analisis univariat dan 
analisis bivariat. Analisi univariat dengan memberikan deskripsi dalam bentuk persentase yang disajikan dalam bentuk tabel dan narasi.Analisis bivariat untuk menganalisa hubungan antara asupan energi dan aktifitas fisik dengan kebugaran jasmani. Jumlah sampel $(\mathrm{n}=30)$ sehingga uji normalitas yang digunakan adalah Shapiro Wilk. Untuk menguji hubungan antara asupan energi dengan kebugaran jasmani atau aktivitas fisik dengan kebugaran jasmani, jika distribusi data normal maka uji yang digunakan adalah Pearson Product Moment, sedangkan jika distribusi data tidak normal maka uji yang digunakan adalah Rank Spearman.Hasil penelitian dikatakan signifikan berhubungan jika nilai probability $(\mathrm{p}<0,05)$

\section{HASIL PENELITIAN}

\section{Karakteristik Subjek Penelitian}

Dalam penelitian ini yang masuk ke dalam karakteristik subjek penelitian meliputi Indeks Massa Tubuh, Aktifitas Fisik, Kebugaran Jasmani, Tingkat Cukupan Energi dan jenis kelamin. Distribusi frekuensi berdasarkan karakteristik subjek dari penelitian ini ditunjukkan dalam tabel di bawah ini.

Tabel 1. Distribusi Frekuensi Berdasarkan Karakteristik Subjek Penelitian

\begin{tabular}{|c|c|c|c|}
\hline No. & Variabel & $\mathbf{n}$ & $\%$ \\
\hline \multirow[t]{4}{*}{1} & Indeks Massa Tubuh & & \\
\hline & a. Kurus & 1 & 3 \\
\hline & b. Normal & 22 & 66 \\
\hline & c. Gemuk & 10 & 30 \\
\hline \multirow[t]{4}{*}{2} & Aktifitas Fisik & & \\
\hline & a. Ringan & 33 & 100 \\
\hline & b. Sedang & 0 & 0 \\
\hline & c. Berat & 0 & 0 \\
\hline \multirow[t]{4}{*}{3} & Kebugaran Jasmani & & \\
\hline & a. Kurang & 27 & 81,8 \\
\hline & b. Sedang & 6 & 18,2 \\
\hline & c. Baik & 0 & 0 \\
\hline \multirow[t]{5}{*}{4} & Tingkat Kecukupan Energi & & \\
\hline & a. Baik & 4 & 12,1 \\
\hline & b. Sedang & 5 & 15,2 \\
\hline & c. Kurang & 6 & 18,2 \\
\hline & d. Defisit & 18 & 54,5 \\
\hline
\end{tabular}




\begin{tabular}{llll}
\hline No. & \multicolumn{1}{c}{ Variabel } & n & \% \\
\hline 6 & Jenis Kelamin & & \\
& a. Laki-laki & 19 & 57,6 \\
& b. $\quad$ Perempuan & 14 & 42,4 \\
\hline
\end{tabular}

Berdasarkan tabel 1, Indeks Massa Tubuh (IMT) dibagi dalam tiga kategori yaitu kurus, normal dan gemuk.Sejumlah $22 \quad(66 \%)$ responden masuk dalam kategori IMT normal.Aktifitas fisik dibagi dalam tiga kategori yaitu ringan, sedang dan berat.Semua subjek penelitian sebesar 33 (100\%) responden masuk kategori aktifitas fisik ringan.Kebugaran jasmani dibagi dalam tiga kategori yaitu kurang, sedang dan baik. Dari hasil analisis menunjukkan jumlah paling besar adalah responden yang masuk dalam kategori kebugaran kurang yaitu sebesar $27(81,8 \%)$ responden. Tingkat kecukupan energi dibagi dalam empat kategori yaitu baik, sedang, kurang dan defisit. Persentasi terbesar adalah responden yang masuk dalam kategori tingkat kecukupan energi defisit yaitu sebesar $18 \quad(54,5 \%)$ responden. Sedangkan dari distribusi karakteristik jenis kelamin menunjukkan sebesar $19 \quad(57,6 \%)$ anak adalah laki-laki dan 14 (42,4\%) anak adalah perempuan.

Hubungan Asupan Energi dengan Kebugaran Jasmani

Untuk mengetahui hubungan antara asupan energi dengan kebugaran jasmani, tahapan pertama dilakukan uji normalitas pada distribusi data yang ada dengan menggunakan Shapiro Wilk.Kemudian untuk menguji hubungan antara dua variabel yang memiliki distribusi data normal menggunakan Pearson Product Moment Test. Berikut adalah hasil analisis hubungan antara variabel asupan energi dengan tingkat kebugaran. 
Tabel 2. Hubungan Asupan Energi dengan Kebugaran Jasmani

\begin{tabular}{llll}
\hline \multicolumn{1}{c}{ Variabel } & N & Mean \pm SD & p \\
\hline Asupan Energi & 33 & $71,87 \pm 24,17$ & \multirow{2}{*}{0,413} \\
Kebugaran jasmani & 33 & $59,36 \pm 5,54$ & \\
\hline
\end{tabular}

Analisis dengan menggunakan Pearson Product Moment Test

Tingkat kepercayaan $95 \%$ signifikan jika nilai $\mathrm{p} \leq 0,05$

Nilai signifikan ditunjukkan dengan notasi $*$ )

Hasil uji statistik Uji normalitas pada distribusi menunjukkan tidak ada hubungan data menunjukkan bahwa ditribusi yang signifikan antara asupan energi datanya tidak normal sehingga uji dengan kebugaran jasmani $(\mathrm{p}=$ hubungan dengan menggunkan 0,413).

Rank-Spearman Test. Berikut adalah hasil analisis hubungan antara

Hubungan Aktifitas Fisik dengan variabel aktifitas fisik dengan tingkat Kebugaran Jasmani kebugaran.

Tabel 3. Hubungan Aktifitas Fisik dengan Kebugaran Jasmani

\begin{tabular}{llll}
\hline Variabel & N & Mean \pm SD & p \\
\hline Aktifitas Fisik & 33 & $0,44 \pm 0,05$ & \multirow{2}{*}{0,297} \\
Kebugaran jasmani & 33 & $59,36 \pm 5,54$ & \\
\hline Analisis dengan menggunakan Rank-Spearman & Test & & \\
Tingkat kepercayaan 95\% signifikan jika nilai & p $\leq 0,05$ & & \\
Nilai signifikan ditunjukkan dengan notasi *) & & &
\end{tabular}

Hasil uji statistik datanya tidak normal sehingga uji menunjukkan tidak ada hubungan hubungan dengan menggunakan yang signifikan antara aktifitas fisik Rank-Spearman Test.Berikut adalah dengan kebugaran jasmani dengan hasil analisis hubungan antara $(\mathrm{p}=0,297)$. variabel Indeks Massa Tubuh dengan tingkat kebugaran.Tabel dibawah

\section{Hubungan Indeks Massa Tubuh dengan Kebugaran Jasmani} menunjukkan hasil analisis hubungan antara dua variabel tersebut.

Uji normalitas pada distribusi data menunjukkan bahwa ditribusi 
Tabel 4. Hubungan Indeks Massa Tubuh dengan Kebugaran Jasmani

\begin{tabular}{llll}
\hline \multicolumn{1}{c}{ Variabel } & N & Mean \pm SD & p \\
\hline Indeks Massa Tubuh & 33 & $16,20 \pm 3,72$ & 0,829 \\
Kebugaran jasmani & 33 & $59,36 \pm 5,54$ & \\
\hline Analisis dengan menggunakan Rank-Spearman Test & & \\
Tingkat kepercayaan 95\% signifikan jika nilai & $\leq 0,05$ & & \\
Nilai signifikan ditunjukkan dengan notasi *) & & &
\end{tabular}

Hasil uji statistik Pada penelitian ini status menunjukkan bahwa tidak hubungan kebugaran anak SD-IT Albina bermakna antara Indeks Massa Purwakarta didapatkan berdasarkan Tubuh dengan kebugaran jasmani tes Harvard Step Test dengan hasil dengan $(\mathrm{p}=0,829)$.

lebih banyak responden yang tergolong kategori kebugaran kurang

\section{PEMBAHASAN}

\section{Kebugaran Jasmani}

Pada penelitian ini data kebugaran didapatkan dengan menggunakan metode Harvad Step Test. Metode tes kebugaran ini merupakan metode tes kebugaran secara tidak langsungyaitu dengan memberikan aktivitas fisik hingga mencapai ambilan oksigen maksimum, kemudian dilakukan perhitungan denyut nadi untuk menggambarkan kemampuan kardiorespiratori dalam pemenuhan oksigen. Tingkat kebugaran ini dapat diketahui dengan refleksi kapasitas aerobik pada detak jantung atau denyut nadi. ${ }^{8}$ yaitu sebesar $27(81 \%)$ responden. Hal ini sejalan dengan hasil penelitian yang dilakukan pada mahasiswa Departemen Arsitektur UI Angkatan 2010 berdasarkan standar tes bangku 3 menit YMCA dengan hasil lebih banyak responden yang tergolong tidak bugar $(88,7 \%)$ dibandingkan dengan yang tergolong bugar $(11,3 \%){ }^{9}$

\section{Asupan Energi}

Asupan energi adalah jumlah total energi yang bersumber dari makanan yang dikonsumsi. ${ }^{10}$ Batas asupan energi menurut AKG untuk anak usia umur 10-12 tahun adalah 2100 kkal untuk anak laki-laki dan 2000 kkal untuk anak perempuan. 
Hasil analisis dari penelitian ini menunjukkan rata-rata jumlah asupan energi responden adalah 1300 kkal (1,9 \% AKG) dan tergolong kurang karena masih $<80 \%$. Dalam penelitian ini, hasil analisis menunjukkan bahwa sebagian besar respondenmasuk dalam kategori defisit yaitu sebesar 18 (54\%) responden. Asupan energi yang kurang pada responden dapat disebabkan oleh padatnya jam pelajaran pada hari-hari sekolah dan kecenderungan lebih banyak bermain pada hari libur sehingga terkadang melupakan waktu makan, selain itu pengawasan dari orang tua agar jumlah dari asupan energi anak yang belum optimal. Pada sebagian kecil responden yang mempunyai asupan energi berada dalam kategori baik dapat disebabkan karena responden memang memiliki nafsu makan yang lebih baik dan kebiasaan mengkonsumsi cemilan atau makanan jajanan.Hasil penelitian ini juga sejalan dengan hasil penelitian yang dilakukan pada mahasiswa Departemen Arsitektur Universitas Indonesia Angkatan 2010 dengan hasil yang menunjukkan bahwa sebagian besar responden memiliki konsumsi energi yang kurang yaitu sebesar $(71,7 \%){ }^{9}$

\section{Aktifitas Fisik}

Aktifitas fisik Aktifitas fisik adalah setiap gerakan tubuh yang dihasilkan oleh otot rangka yang memerlukan pengeluaran energi. ${ }^{3}$

Aktifitas fisik tergolong berat jika hasil perhitungan dari recall akftifitas fisik>2,09, sedang antara 1,76-2,09, dan ringan jika $<1,76$. Berdasarkan hasil analisis aktifitas fisik menunjukkan bahwa semua responden masuk dalam kategori aktifitas fisik ringan (100\%).Hasil ini dapat disebabkan oleh faktor umur dan sebagian besar responden tidak memiliki jadwal rutin melakukan aktifitas yang lebih berat seperti berolah raga. Hasil penelitian ini sama dengan hasil penelitian yang dilakukan oleh Sidratulmuntaha pada siswa Sekolah Polisi Negara Batua Makassar dengan hasil sebagian besar responden tergolong aktifitas ringan yaitu sebesar $(97,4 \%){ }^{11}$ 
Hubungan Asupan Energi dengan

\section{kebugaran jasmani}

Konsumsi energi yang optimal dan pengeluaran energi merupakan hal yang penting bagi individu terutama untuk individu yang aktif. Dapat dibayangkan ketika asupan energi seseorang tidak mencukupi kebutuhan energi yang dibutuhkan maka akan sulit untuk melakukan aktifitas dengan optimal.

Sementara itu, dari hasil analisis penelitian ini menunjukkan bahwa tidak terdapat hubungan yang bermakna antara asupan energi dengan kebugaran jasmani pada siswa SD-IT Albina Purwakarta dengan $\quad(p=0,413)$. Hasil ini kemungkinan bisa disebabkan karena data asupanmakan dan energi yang didapatkan menunjukkan bahwa asupan energi responden rataratakurang mencukupi kebutuhannya danselain itukebugaran jasmani dapat ditentukan juga oleh faktor lain selainasupan makan.

Hasil ini sejalan dengan hasil penelitian yang dilakukan pada 370 responden dariSMA N 4 Yogyakarta, SMA N 9 Yogyakarta, SMA Piri 1 Yogyakarta, SMA Muhammadiyah 3
Yogyakarta, dan SMA Muhammadiyah 5 Yogyakarta yang menunjukkan bahwa tidak ada hubungan signifikan antara asupan energi dengan kebugaran dengan $(\mathrm{p}=0,735){ }^{12}$

Hasil ini tidak sejalan dengan penelitian yang dilakukan pada 50 responden dari peserta fitness di Virenka Gym Batul-Yogyakarta yang menyatakan bahwa ada hubungan yang bermakna antara asupan energi dengan tingkat kebugaran dengan $\quad(p=0,001) \cdot{ }^{13}$ Begitu pula tidak sejalan dengan teori yang menyebutkan bahwaenergi dan zat gizi yang seimbang menjadi syarat utama penentu tingkat produktivitas kerja. ${ }^{14}$

Hasil penelitian ini yang tidak sejalandengan penelitian lain dan teori dapat disebabkan karenadari hasil recall 24 jam yang dilakukan dua kali pada responden diperoleh data asupanmakan dan energi yang rata-ratakurang mencukupi kebutuhannya danselain kebugaran jasmani dapat ditentukan juga oleh faktor lain selainasupan makan yaitu diantaranya adalahfaktor 
aktifitasfisik, genetik, umur, jenis kelamin dan status gizi.

\section{Hubungan Aktifitas Fisik dengan kebugaran jasmani}

Aktifitas fisik yang teratur dan bervariasi dapat memberikan efek peningkatan daya tahan kardiorespiratori, penurunan detak jantung dan tekanan darah, peningkatan efisiensi kerja otot jantung, peningkatan ketahanan dalam melakukan aktifitas fisik, peningkatan kekuatan otot dan peningkatan metabolisme tubuh. ${ }^{15}$

Hasil analisis data menunjukkan bahwa sebagian besar responden status kebugaran mereka berada dalam kategori kurang yaitu $27 \quad(81,8 \%)$ dan analisis menunjukkan bahwa tidak ada hubungan antara aktifitas fisik dengan kebugaran jasmani dengan $(\mathrm{p}=0,297)$.

Hasil ini sejalan dengan penelitian yang dilakukan pada 193 responden dari siswa Diktuk Brigadir Dalmas SPN Batua Makassar yang menunjukkan bahwa tidak ada hubungan yang signifikan antara aktifitas fisik dengan ketahanan fisik sebagai indikator kebugaran jasmani dengan $(\mathrm{p}=0,818) .{ }^{10}$

$$
\text { Secara teori, dengan }
$$
meningkatkan aktifitas fisik dengan cara latihan fisik atau olahraga yang baik dan teratur dapat meningkatkan derajat kebugaran jasmani. ${ }^{16}$ Begitu pula dari penelitian sebelumnya yang dilakukan pada 108 mahasiswa dari Fakultas Teknik Universitas Indonesia menunjukkan bahwa terdapat hubungan yang signifikan antara aktifitas fisik dengan kebugaran $(\mathrm{p}=0,042) .{ }^{9}$

Hasil penelitian ini berbeda dengan teori dan penelitian sebelumnya bisa disebabkan oleh data aktifitas fisik yang didapatkan dari responden tidak terdapat variasi kategori aktifitas fisik yang dilakukan oleh siswa kelas V SD-IT Albina Purwakarta, dan data yang diperoleh hanya dilihat dan diukur pada saat penelitian berlangsung saja. Dan seperti disebutkan sebelumnya bahwa kebugaran jasmani dapat ditentukan juga oleh faktor lain selainasupan makan yaitu diantaranya adalahfaktor genetik, umur, jenis kelamin dan status gizi. 


\section{SIMPULAN}

Terdapat $27(81,8 \%)$ responden masuk dalam kategori kebugaran kurang, $6 \quad(18,2 \%) \quad$ orang respondenmasuk dalam kategori kebugaran sedang dan tidak ada $(0 \%)$ responden yang masuk dalam kategori kebugaran baik. Terdapat4 $(21,1 \%)$ responden masuk dalam kategori Tingkat Kecukupan Energi baik, 5 (15,2\%)responden masuk kategori sedang, 6 (18,2\%)orang responden masuk kategori kurang dan sebanyak $18(54,5 \%)$ responden masuk dalam kategori defisit.Semua responden $(100 \%)$ termasuk dalam kategori aktifiras fisik ringan.Tidak ada hubungan antara asupan energi dengan kebugaran jasmani $(\mathrm{p}=$ 0,413). Tidak ada hubungan antara aktifitas fisik dengan kebugaran jasmani ( $p=0,297)$.

\section{DAFTAR PUSTAKA}

1. Kosasih, E. Olahraga: Teknik Dan Program Latihan.Jakarta: CV. Akademika Presindo; 1985.

2. Maksum, A. Sport Development Index Bukan Kontra Prestasi. Diunduh dari URL: http://www.bulutangkis.com/mo d.php? $\bmod =$ publisher\&op=view article\&artid=3026. Di akses pada 13 Mei 2016.

3. WHO. Physical Activity. Diunduh dari URL: http://www.who.int/topics/physi cal_activity/en/. Diakses pada 13 Mei 2016.

4. Tarigan, B.Pendidikan Jasmani Adaptif. Bandung: Jurusan Pendidikan Olah raga; 2008.

5. Sulastri. Pengaruh Kebugaran Jasmani Dan Prestasi Belajar Pendidikan Jasmani Terhadap Perilaku Sosial Siswa.Jurnal llmiah Guru "COPE". 2015; (1).

6. Indrawagita, L. Hubungan Status Gizi, Asupan Gizi dan Aktivitas Fisik pada Mahasiswa Program Studi Gizi FKMUI Tahun 2009 (Undergraduate Thesis). Depok: Universitas Indonesia; 2009.

7. Williams, M. Nutrition for Health, Fitness and Sport. USA: McGraw-Hill Higher Education; 2002.

8. Rowland M, Thomas W. Developmental Exercise Physiology. USA: HumanKinetics; 1996. 
9. Nurwidyastuti, D. Hubungan

(Undergraduate

Thesis).

Konsumsi Zat Gizi, Status Gizi,

Yogyakarta:Universitas Gadjah

dan Faktor-faktor lain dengan

Mada; 2015.

Stattus Kebugaran Mahasiswa

Departemen Arsitektur Fakultas

Teknik Universitas Indonesia

Tahun 2012 (Undergraduate

Thesis). Depok: Universitas

Diponegoro; 2012.

10. Almatsier, S. Prinsip Dasar Ilmu

Gizi. Jakarta: Gramedia; 2004.

11. Jaihar S, Djunaidi MD, Yustini.

Analisis Status Gizi Dan

Aktivitas Fisik Dengan Ketahan

Fisik Siswa Di Sekolah Polisi

Negara (Spn) Batua Makassar

Sulawesi Selatan. Jurnal

Program Studi Ilmu Gizi

Fakultas Kesehatan Masyarakat

Universitas Hasanuddin

Makassar. 2013.

12. Noviantari W, Emy H, I Made

G. Hubungan Aktivitas Fisik dengan Status Kebugaran

Remaja di Yogyakarta

13. Sugiarto. Hubungan Asupan Energi, Protein dan Suplemen dengan Tingkat

Kebugaran.Jurnal Media Ilmu Keolahragaan Indonesia.

Semarang: Universitas Negeri; 2012.

14. Depkes RI. Pedoman Pemenuhan Kecukupan Gizi Pekerja Selama Bekerja. Jakarta: Direktorat Jenderal Bina Kesehatan Masyarakat; 2010.

15. Astrand, P. 1992.

PhysicalActivity and Fithness. American Joural Clinical Nutrition. 1992; 55: 1231S-6S.

16. Widodo BS, Kusnanik NW. 2013. Tingkat Kesegaran Jasmani pada Siswa SMP Negeri 2 Krembung dan SMP Negeri 2 Sidoarjo. Jurnal Prestasi Olahraga. 2013; 1(1): 1-5. 